\title{
The first 9-hydroxyhomoisoflavanone, and antiplasmodial chalcones, from the aerial exudates of Polygonum senegalense
}

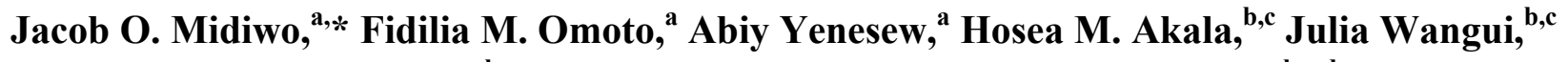 \\ Pamela Liyala, ${ }^{b, c}$ Christine Wasunna, ${ }^{c}$ and Norman C. Waters ${ }^{b, c, d}$ \\ ${ }^{a}$ Department of Chemistry, University of Nairobi, P.O. Box 30197, Nairobi, Kenya \\ ${ }^{b}$ Centre for Clinical research, Kenya Medical Research Institute, P.O. Box 2077800202 , \\ Nairobi, Kenya \\ ${ }^{c}$ United States Army Medical Research Unit-Kenya, MRU 64109, APO, AE 09831-4109, USA \\ ${ }^{d}$ Division of Experimental Therapeutics, Walter Reed Army Institute of Research \\ 503 Robert Grant Avenue, Silver Spring, MD 20910, USA \\ E-mail:jmidiwo@uonbi.ac.ke
}

\section{Dedicated to Professor Berhanu M. Abegaz on his $60^{\text {th }}$ Birthday}

\begin{abstract}
Phytochemical re-examination of the aerial exudates of Polygonum senegalense forma senegalense has resulted in the isolation and characterization of a novel homoisoflavonoid, 5,7dihydroxy-3-(hydroxy-phenyl-methyl)-6-methoxy-chroman-4-one (trivial name: polygohomoisoflavanone). The structure was determined on the basis of spectroscopic evidence. The new compound along with other components of the aerial exudate showed good antiplasmodial activities towards chloroquine-sensitive (D6) and chloroquine-resistant (W2) strains of Plasmodium falciparum.
\end{abstract}

Keywords: Polygonum senegalense, aerial exudates, polygonaceae, homoisoflavanone, polygohomoisoflavanone, chalcones, dihydrochalcones, flavanone, malaria, plasmodium, antiplasmodial

\section{Introduction}

Aerial or leaf exudates have been reported from plant species of many families and are known to consist of a variety of non-polar compounds but mostly flavonoids and terpenoid (or less often fatty acid) milieu. The flavonoids found in the exudates, compared to the internal tissue compounds, are frequently aglycones of chalcones, flavanones and flavones exhibiting increased hydrophobicity through the presence of methoxylated substituents or dehydroxylation in both 
ring $\mathrm{A}$ and $\mathrm{B}$ as compared to the internal tissue forms. The terpenoids are more often diterpenoids of various types and less frequently the triterpenoids, depending on the species. ${ }^{1,2}$ The aerial exudate of Polygonum senegalense has been reported to contain 12 flavonoids of the chalcone and flavanone types, ${ }^{3,4}$ and they are distinctly different from internal tissue aglycones. ${ }^{4}$ Chalcones are being investigated as lead structures for the discovery of anti-malarial drugs. ${ }^{5}$ In continuation of our interest in the anti-plasmodial activities of flavonoids and chalcones, ${ }^{6,7,8}$ we have re-examined the aerial exudates of Polygonum senegalense. We report here the isolation, characterization and anti-plasmodial activities of the first 9-hydroxyhomoisoflavonoid (1), along with the anti-plasmodial activities of some of chalconoids and a flavanone isolated along with it from the surface exudate of $P$. senegalense.

\section{Results and Discussion}

The EIMS molecular ion peak ( $m / z$ 316) and the ${ }^{13} \mathrm{C}$ NMR spectrum (Table 1$)$ established the molecular formula of compound 1 as $\mathrm{C}_{17} \mathrm{H}_{16} \mathrm{O}_{6}$. The UV $\left(\lambda_{\max } 330,288 \mathrm{~nm}\right),{ }^{1} \mathrm{H}(\delta 4.49, d d, J=$ $11.1,-10.2 \mathrm{~Hz}$ for H-2ax; 4.22, $d d, J=5.1,10.2 \mathrm{~Hz}$ for H-2eq; 3.02, $d d d, J=-11.1,8.4,5.4 \mathrm{~Hz}$ for $\mathrm{H}-3$ and $5.00, d, J=8.4 \mathrm{~Hz}$ for $\mathrm{H}-9)$ and ${ }^{13} \mathrm{C} \mathrm{NMR}(\delta 68.5$ for C-2, 51.9 for C-3, 199.6 for C4 and 72.9 for C-9) spectra suggested this compound to be a homoisoflavanone derivative with a hydroxyl substituent at $\mathrm{C}-9$. That this compound has a 9-hydroxyhomoisoflavonoid skeleton was confirmed from ${ }^{1} \mathrm{H},{ }^{1} \mathrm{H}-\mathrm{COSY}$ and $\mathrm{HMBC}$ spectra (Table 1).

The MS, ${ }^{1} \mathrm{H}$ and ${ }^{13} \mathrm{C}$ NMR spectra further showed the presence of two hydroxyl $\left(\delta_{\mathrm{H}} 12.16\right.$ and 6.60 br s) and a methoxyl substituents $\left(\delta_{\mathrm{H}} 3.91\right.$ and $\delta_{\mathrm{C}}$ 61.2) on a 9hydroxyhomoisolfavonoid skeleton. The ${ }^{1} \mathrm{H}$ and ${ }^{13} \mathrm{C}$ NMR spectra further showed a monosubstituted benzene (B-ring), suggesting that the two hydroxyl and the methoxyl substituents are located in A-ring. The fragment ion at $\mathrm{m} / \mathrm{z} 210$ (Scheme 1) resulting from McLafferty rearrangement is consistent with the presence of hydroxyl group at C-9, and also suggested the placement of two hydroxyl and the methoxyl substituents in A-ring. In agreement with this, the ${ }^{1} \mathrm{H}$ spectrum showed a singlet aromatic proton $(\delta 5.99)$ in a tri-substituted A-ring. This singlet showed HMBC correlation with C-8a and hence assigned to H-8. The presence of a deshielded signal at $\delta 12.16$ locates one of the hydroxyl groups at C-5 with the other hydroxyl and the methoxy being at C-6 and C-7. The deshielded chemical shift position of the methoxy carbon $(\delta$ 61.2) is typical of a di-ortho-substituted methoxyl resonance allowing its placement at C-6 rather than C-7. ${ }^{9}$ The HMBC correlation of the methoxy proton with the highly shielded oxygenated aromatic carbon $(\delta$ 128.8) confirmed the placement of the methoxyl at C-6. Hence this new compound is 5,7-dihydroxy-3-(hydroxy-phenyl-methyl)-6-methoxychroman-4-one (structure 1, Figure 1) for which we suggest the trivial name polygohomoisoflavanone, since it is a unique compound from Polygonum senegalense. Although the stereochemistry at C-3 and C-9 is yet to be determined, it is worth to mention that this is the only homoisoflavanone with a hydroxyl substituent at C-9. Further more this compound is unique in that it is the only homoisoflavonoid 
which lacks oxygenation in B-ring. The flavonoids and chalconoids of this plant also lack oxygenation in B-ring and it is likely that the chalcone $\mathbf{2}$ is the biogenetic precursor to $\mathbf{1}$ (Scheme 2).

Table 1. ${ }^{1} \mathrm{H}(500 \mathrm{MHz})$ and ${ }^{13} \mathrm{C}(125 \mathrm{MHz})$ NMR data of $\mathbf{1}$ and $\mathbf{2}$ along with $\mathrm{HMBC}$ correlations (in $\mathrm{CD}_{2} \mathrm{Cl}_{2}$ )

\begin{tabular}{|l|l|l|l|}
\hline Position & ${ }^{1} \mathrm{H}(J$ in $\mathrm{Hz})$ & ${ }^{13} \mathrm{C}$ & $\mathrm{HMBC}\left({ }^{2} J{ }^{3} J\right)$ \\
\hline $\begin{array}{l}2 \mathrm{eq} \\
2 \mathrm{ax}\end{array}$ & $\begin{array}{l}4.22 d d(5.1,-10.2) \\
4.49 d d(-10.2,11.1)\end{array}$ & 68.5 & $\begin{array}{l}\mathrm{C}-4,-8 \mathrm{a} \\
\mathrm{C}-4,-8 \mathrm{a}\end{array}$ \\
\hline $3 \mathrm{ax}$ & $3.02 d d d(5.1,8.4,11.1)$ & 51.9 & $\mathrm{C}-4,-1^{\prime}$ \\
\hline 4 & & 199.6 & \\
\hline $4 \mathrm{a}$ & & 103.9 & \\
\hline 5 & & 155.1 & \\
\hline 6 & & 128.8 & \\
\hline 7 & & 158.3 & \\
\hline 8 & $5.99 s$ & 94.4 & $\mathrm{C}-4 \mathrm{a},-6,-7,-8 \mathrm{a}$ \\
\hline $8 \mathrm{a}$ & & 159.4 & \\
\hline 9 & $5.00 \mathrm{~d}(8.4)$ & 72.9 & $\mathrm{C}-2,-3,-1^{\prime},-2^{\prime}, 6^{\prime}$ \\
\hline $1^{\prime}$ & & 141.3 & \\
\hline $2^{\prime} / 6{ }^{\prime}$ & $7.40 m$ & 127.0 & $\mathrm{C}-9,-4^{\prime}$ \\
\hline $3^{\prime} / 5^{\prime}$ & $7.36 m$ & 128.7 & $\mathrm{C}-1^{\prime}$ \\
\hline $4^{\prime}$ & $7.25 m$ & 128.0 & $\mathrm{C}-2^{\prime}, 6^{\prime}$ \\
\hline OMe & $3.91 s$ & 61.2 & $\mathrm{C}-6$ \\
\hline OH-5 & $12.16 s$ & & $\mathrm{C}-5,-6$ \\
\hline OH-7 & $6.60 \mathrm{br} s$ & & \\
\hline OH-9 & & & \\
\hline
\end{tabular}




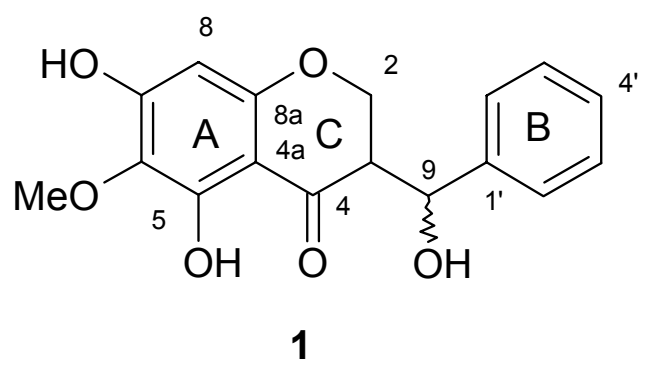<smiles>[R2]c1cc([R3])c(C(=O)CCc2ccccc2)c(O)c1[R1]</smiles>

$6 \mathrm{R}_{1}=\mathrm{H}, \mathrm{R}_{2}=\mathrm{OMe}, \mathrm{R}_{3}=\mathrm{OH}$

$7 \mathrm{R}_{1}=\mathrm{R}_{2}=\mathrm{OMe}, \mathrm{R}_{3}=\mathrm{OH}$<smiles>[R]c1cc([R3])c(C(=O)/C=C/c2ccccc2)c(O)c1[R1]</smiles>

$2 \mathrm{R}_{1}=\mathrm{R}_{3}=\mathrm{OMe}, \mathrm{R}_{2}=\mathrm{OH}$

$3 \mathrm{R}_{1}=\mathrm{H}, \mathrm{R}_{2}=\mathrm{R}_{3}=\mathrm{OMe}$

$4 \mathrm{R}_{1}=\mathrm{H}, \mathrm{R}_{2}=\mathrm{OH}, \mathrm{R}_{3}=\mathrm{OMe}$

$5 \quad \mathrm{R}_{1}=\mathrm{R}_{2}$, OMe, $\mathrm{R}_{3}=\mathrm{OH}$

Figure 1. Structure of polygohomoisoflavanone (1) and other compounds isolated from Polygonum senegalense.<smiles>COc1cc(O)c2c(c1)OC(c1ccccc1)CC2=O</smiles>

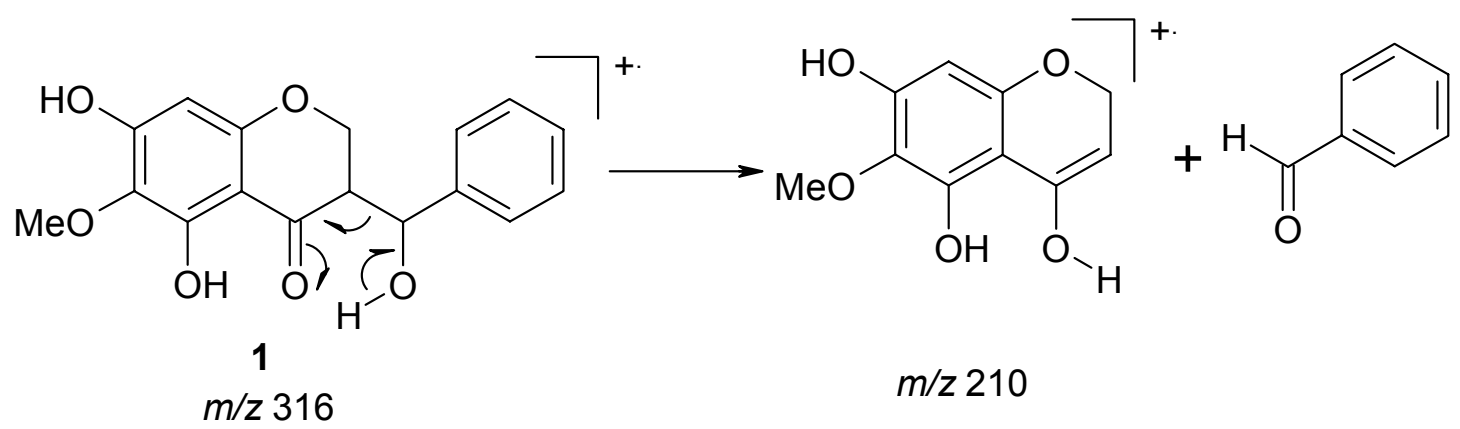

Scheme 1. McLafferty rearrangement in $\mathbf{1 .}$ 


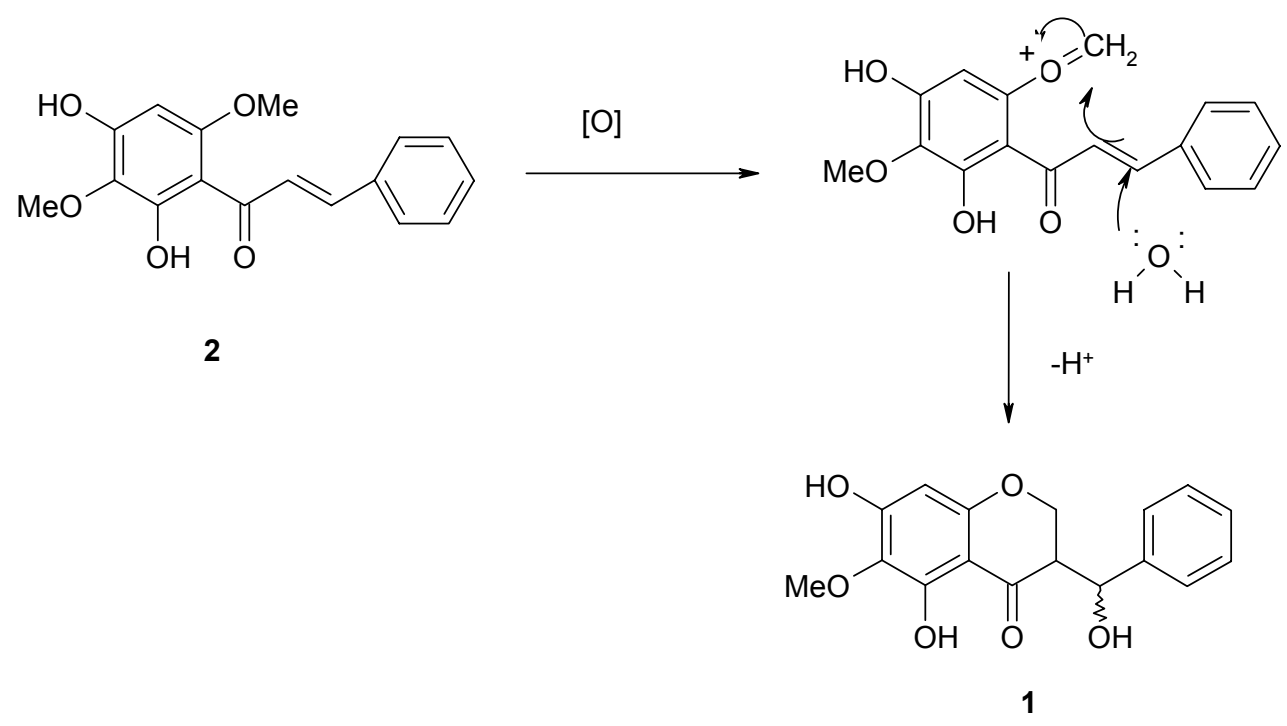

Scheme 2. Proposed biogenesis of compound 1 from 2.

The new compound (1) as well as some of the chalcones, dihydrochalcones and a flavanone isolated from this plant (Figure 1) were tested for anti-plasmodial activity against the D6 and W2 strains of $P$. falciparum. The results are presented in table 2. All eight compounds demonstrate significant activity against the malaria parasite without any major inhibitor selectivity differences between the two strains of P. falciparum (Table 2). These chalcones and dihydrochalcones have identical A-ring and differ on the substitution pattern in ring $\mathrm{B}$. Among these compounds the chalcone $\mathbf{5}$ is the most active showing $\mathrm{IC}_{50}$ under $5 \mu \mathrm{M}$. The antiplasmodial activities of chalcones is well documented, with 2,4-dimethoxy-4'-butoxychalcone having an outstanding antimalarial activity. ${ }^{5}$

Table 2. In vitro anti-plasmodial activities of flavonoids and chalcones of Polygonum senegalense against the D6 and W2 strains of Plasmodium falciparum

\begin{tabular}{lcc}
\hline Compounds & \multicolumn{2}{c}{$\left(\mathrm{IC}_{50}\right.$ in $\left.\mu \mathrm{M}\right)$} \\
\cline { 2 - 3 } & $\mathrm{D} 6$ & $\mathrm{~W} 2$ \\
\hline $\mathbf{1}$ & $19.2 \pm 0.6$ & $18.2 \pm 1.8$ \\
$\mathbf{2}$ & $16.6 \pm 2.3$ & $17.8 \pm 0.08$ \\
$\mathbf{3}$ & $15.7 \pm 1.2$ & $11.3 \pm 0.2$ \\
$\mathbf{4}$ & $14.0 \pm 1.7$ & $9.5 \pm 1.1$ \\
$\mathbf{5}$ & $3.1 \pm 0.8$ & $2.4 \pm 0.3$ \\
$\mathbf{6}$ & $23.5 \pm 0.8$ & $22.8 \pm 1.8$ \\
$\mathbf{7}$ & $11.8 \pm 0.3$ & $12.9 \pm 0.5$ \\
$\mathbf{8}$ & $16.3 \pm 1.8$ & $21.8 \pm 1.2$ \\
Reference drugs & & \\
Chloroquine & $0.008 \pm 0.002$ & $0.075 \pm 0.002$ \\
Quinine & $0.050 \pm 0.02$ & $0.28 \pm 0.02$ \\
\hline
\end{tabular}




\section{Experimental Section}

General Procedures. Analytical TLC: Merck pre-coated silica gel $60 \mathrm{~F}_{254}$ plates. $\mathrm{CC}$ on silica gel 60 (70-230 mesh). EIMS: direct inlet, $70 \mathrm{eV}$, JEOL JMS-D 300 mass spectrometer. ${ }^{1} \mathrm{H}$ and ${ }^{13} \mathrm{C}$ NMR on Bruker DRX-500 spectrometer with TMS as int. standard. HMQC and HMBC spectra were acquired using the standard Bruker software.

Plant material. Polygonum senegalense forma senegalense was collected from along the banks of Nairobi River within the premises of the University of Nairobi, Chiromo campus. Authentication of the plant material has been described. ${ }^{3,4}$

Extraction and isolation. The fresh aerial parts of Polygonum senegalense forma senegalense were extracted by dipping them in acetone for ca. 15 seconds. ${ }^{4}$ Removal of the solvent gave a dark brown gummy residue $(21.4 \mathrm{~g})$ from a dry weight of $205 \mathrm{~g}$ of the plant material. The exudate was chromatographed over silica gel eluting with petroleum ether $\left(60-80^{\circ} \mathrm{C}\right)$, benzene, chloroform and then with methanol to give four major fractions (A-D). Further chromatography (silica gel, petroleum ether and chloroform mixtures as eluents) of fraction $C$ gave compound $\mathbf{1}(120 \mathrm{mg})$. The isolation and characterisation of the other compounds used for anti-plasmodial test have been described. $^{3,4}$

Polygohomoisoflavanone (1). White crystals from dichloromethane-hexane, mp $134-135{ }^{\circ} \mathrm{C} .[\alpha]_{\mathrm{D}}$ $+41^{\circ}$ (c 0.1, MeOH). UV $\lambda_{\max }(\mathrm{MeOH}): 330,288 \mathrm{~nm}$. IR $v_{\max }$ : 3420, 3340br, 3060, 2925, 2840, 1620, 1580, 1510, 1485, 1400, 1315, 1245, $1155 \mathrm{~cm}^{-1} .{ }^{1} \mathrm{H}$ NMR (Table 1). ${ }^{13} \mathrm{C}$ NMR (Table 1). EIMS $m / z$ (rel. int.): $\left.316(46, \mathrm{M}]^{+}\right), 210\left(100,\left[\mathrm{C}_{10} \mathrm{H}_{10} \mathrm{O}_{5}\right]^{+}\right), 195$ (54), 167(15), 255 (22).

In vitro antiplasmodial activity. The anti-plasmodial activity assay, against the chloroquinesensitive (D6) and chloroquine-resistant (W2) strains of $P$. falciparum using a $\left[{ }^{3} \mathrm{H}\right]$ hypoxanthine uptake, was done as described earlier. ${ }^{6}$

\section{References}

1. Wollenweber, E. In Flavonoids and Bioflavonoids; Farkas, L; Gabor, M.; Kallay, F.; Eds., Institute of Botany: University of Darmstadt, Germany. 1985, p 155.

2. Wollenweber, E.; Hradetsky, E.; Mann, K.; Roitman, J. N.; Yatskievitch, G.; Proksch, P. J. Plant Physiol. 1987, 131, 37.

3. Midiwo, J. O.; Matasi, J. J.; Wanjau, O. M.; Mwangi, R. W.; Waterman, P.G.; Wollenweber, E. Bull. Chem. Soc. Ethiop. 1990, 4, 123.

4. Midiwo, J. O.; Gikonyo, N. K.; Wanjau, O. M.; Matasi, J. J.; Waterman, P.G. Bull. Chem. Soc. Ethiop. 1992, 6, 119.

5. Liu, M.; Wilairat, P.; Go, M.-L. J. Med. Chem. 2001, 44, 4443.

6. Yenesew, A.; Derese, S.; Irungu, B.; Midiwo, J. O.; Waters, N. C.; Liyala, P.; Akala, H.; Heydenreich, M.; Peter, M. G. Planta Medica 2003, 69, 658. 
7. Yenesew, A.; Induli, M.; Derese, S.; Midiwo, J. O.; Heydenreich, M.; Peter, M. G.; Akala, H.; Wangui, J.; Liyala, P.; Waters, N. C. Phytochemistry 2004, 65, 3029.

8. Andayi, A. W.; Yenesew, A.; Derese, S.; Midiwo, J. O.; Gitu, P. M.; Jondiko, I. O.; Waters, N. C.; Liyala, P.; Akala, H.; Heydenreich, M.; Peter, M. G. Planta Medica 2006, 72, 187.

9. Panichpol, K.; Waterman, P. G. Phytochemistry 1978, 31, 2863. 